\title{
A new deep-sea Cirripedia of the genus Heteralepas from the northeastern Atlantic
}

\author{
Jorge Lobo ${ }^{1, *} \&$ Miriam Tuaty-Guerra ${ }^{2}$ \\ ${ }^{1,2}$ Instituto Português do Mar e da Atmosfera, I.P. (IPMA), \\ Rua Alfredo Magalhães Ramalho, 6, 1495-006 Lisboa, Portugal. \\ ${ }^{1}$ Centro de Ciências do Mar e do Ambiente (MARE), Universidade Nova de Lisboa, \\ Campus de Caparica, 2829-516 Caparica, Portugal. \\ * Corresponding author: j.loboarteaga@gmail.com \\ 2Email: mguerra@ipma.pt \\ ${ }^{1}$ urn:Isid:zoobank.org:author:5B47E4EE-BAE5-4707-A0CC-83E01DA8F254 \\ ${ }^{2}$ urn:1sid:zoobank.org:author:5F3EA929-9041-4C3A-941A-A9CEE0524ADA
}

\begin{abstract}
A new species of the sessile deep-sea barnacle, Heteralepas (Crustacea, Cirripedia), Heteralepas gettysburgensis sp. nov., is described. The specimens were collected at a depth of $225 \mathrm{~m}$ at the Gettysburg Seamount on the Gorringe Bank, located in the Portuguese Exclusive Economic Zone, approximately $200 \mathrm{~km}$ off the southwestern coast of mainland Portugal. Extensive morphological and molecular (COI, 12S and 16S) analyses were carried out to separate the species from its nearest congeners with similar geographic distribution, i.e., Atlantic waters.
\end{abstract}

Keywords. Gorringe Bank, Lepadiformes, naked barnacle, seamount.

Lobo J. \& Tuaty-Guerra M. 2017 A new deep-sea Cirripedia of the genus Heteralepas from the northeastern Atlantic. European Journal of Taxonomy 385: 1-14. https://doi.org/10.5852/ejt.2017.385

\section{Introduction}

A hydrophone, deployed on 23 August 2015, was collected from a depth of $255 \mathrm{~m}$ at the Gettysburg seamount (36 $\left.34^{\prime} 42.46^{\prime \prime} \mathrm{N}, 11^{\circ} 35^{\prime} 49.02^{\prime \prime} \mathrm{W}\right)$, located in the Gorringe Bank in the Madeira-Tore geological complex (North-East Atlantic), on 28 August 2016. It was fully colonized by polyps of the hydrozoan Oceania armata Kölliker, 1853 and specimens of the new species of Heteralepas Pilsbry, 1907 proposed in this study.

Currently, twenty-three species of the genus Heteralepas are accepted at the World Register of Marine Species (Chan \& Southward 2010). All species are distributed in the Atlantic, Pacific and Indo-Pacific waters. However, only six species are registered for the Atlantic, of which three are for the eastern Atlantic.

We carried out comparisons of our specimens to species with similar diagnostic characters and to species with close geographic distribution, i.e., Atlantic waters. None of the previously described species 
matches, neither morphologically nor genetically, the new species Heteralepas gettysburgensis sp. nov. presented here.

\section{Material and methods}

Specimens were collected from a depth of $255 \mathrm{~m}$ at the Gettysburg Seamount $\left(36^{\circ} 34^{\prime} 42.46^{\prime \prime} \mathrm{N}\right.$, $11^{\circ} 35^{\prime} 49.02^{\prime \prime} \mathrm{W}$ ) in the Gorringe Bank, located in the Madeira-Tore geologic complex (Fig. 1). Fifteen specimens were morphologically analyzed, of which ten were dissected for the analysis of internal characters and five for molecular analyses.

For the morphological analysis, an optical microscope (Leica MZ 12) was used. Drawings were made using a camera lucida attached to the optical microscope. Pictures were obtained with a digital camera (SONY DFW-SX910) connected to an optical microscope (OLYMPUS SZX9), using an image analyser (Visilog, TNPC Software, v.4).

A small piece of muscle tissue from each of the five specimens was used for DNA extraction using the E.Z.N.A Mollusc DNA Kit (Omega Biotek), following the manufacturer's instructions. Three mitochondrial genetic markers (the barcode region of the cytochrome $c$ oxidase subunit I (COI5P), 12S and 16S) were amplified in a Techne TC-PLUS thermal cycler (VWR International, LLC, Radnor, USA). For the COI-5P, the Go Taq ${ }^{\circledR}$ G2 colorless master mix (Promega) and the primer pair LoboF1 (5'-KBTCHACAAAYCAYAARGAYATHGG-3') and LoboR1

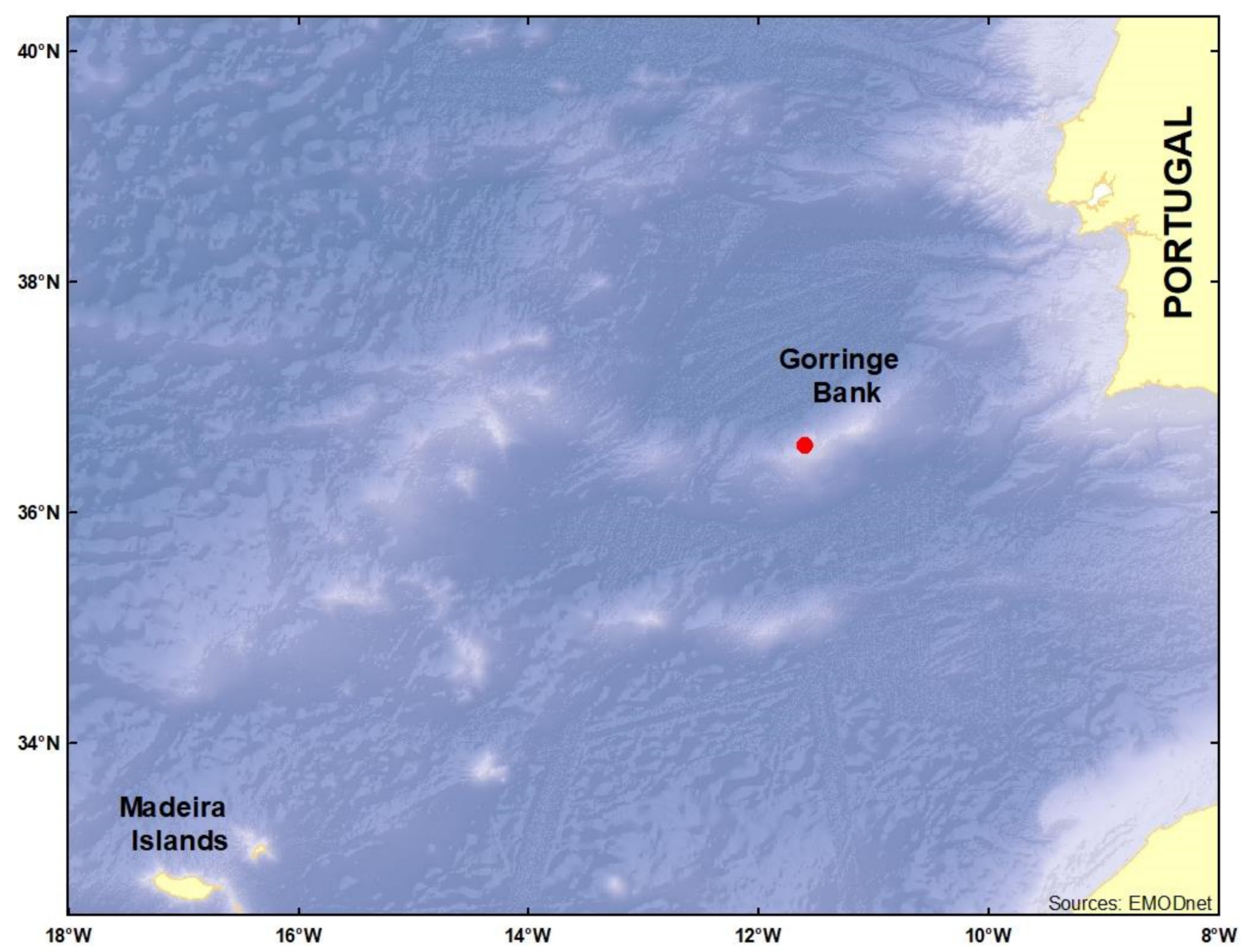

Fig. 1. Map showing the location of the sampling site (red dot). 
(5'-TAAACYTCWGGRTGWCCRAARAAYCA-3') (Lobo et al. 2013) were used. The PCR thermal cycling conditions were as follows: 1$) 94^{\circ} \mathrm{C}\left(5^{\prime}\right)$; 2) 5 cycles: $\left.94{ }^{\circ} \mathrm{C}\left(30^{\prime \prime}\right), 45^{\circ} \mathrm{C}\left(1 ' 30^{\prime \prime}\right), 72^{\circ} \mathrm{C}\left(1^{\prime}\right) ; 3\right)$ 45 cycles: $94^{\circ} \mathrm{C}\left(30^{\prime \prime}\right), 54^{\circ} \mathrm{C}\left(1^{\prime} 30^{\prime \prime}\right), 72^{\circ} \mathrm{C}\left(1^{\prime}\right)$; 4$) 72^{\circ} \mathrm{C}\left(5^{\prime}\right)$. Each reaction contained $12.5 \mu \mathrm{L} 1 \times$ Go Taq master mix plus $10 \mu \mathrm{m}$ of each primer (1.5 $\mu \mathrm{L}$ for each primer), $4 \mu \mathrm{L}$ of DNA template and completed with sterile milliQ-grade water to make up a total volume of $25 \mu \mathrm{L}$. For 12S, puRe Taq Ready-To-Go PCR beads (Amersham Biosciences) and the primer pair L13337-12S (YCTACTWTGYTACGACTTATCTC; Machida et al. 2002) and H13842-12S (TGTGCCAGCASCTGCGGTTAKAC; Machida et al. 2004) were used by performing the following thermal cycling conditions: 1) $94^{\circ} \mathrm{C}\left(5^{\prime}\right)$; 2) 40 cycles: $94{ }^{\circ} \mathrm{C}\left(5^{\prime \prime}\right), 45$ ${ }^{\circ} \mathrm{C}\left(5^{\prime \prime}\right), 72{ }^{\circ} \mathrm{C}(10 ")$. Each reaction contained $4 \mu \mathrm{L}$ of DNA template, $1 \mu \mathrm{L}(10 \mu \mathrm{m})$ of each primer and completed with sterile milliQ-grade water to make up a total volume of $25 \mu \mathrm{L}$. For $16 \mathrm{~S}$, puRe Taq ReadyTo-Go PCR beads (Amersham Biosciences) and the primer pair 16L2 (TGCCTGTTTATCAAAAACAT; Schubart et al. 2002) and 16H2 (AGATAGAAACCAACCTGG; Schubart et al. 2000) were used by performing the following thermal cycling conditions: 1) $94{ }^{\circ} \mathrm{C}\left(4^{\prime}\right)$; 2) 35 cycles: $95^{\circ} \mathrm{C}\left(45^{\prime \prime}\right), 48{ }^{\circ} \mathrm{C}$ (45"), $\left.72^{\circ} \mathrm{C}\left(1{ }^{\prime} 30^{\prime \prime}\right) ; 3\right) 72^{\circ} \mathrm{C}\left(5^{\prime}\right)$. Each reaction contained $4 \mu \mathrm{L}$ of DNA template, $1 \mu \mathrm{L}(10 \mu \mathrm{m})$ of each primer and completed with sterile milliQ-grade water to make up a total volume of $25 \mu \mathrm{L}$. COI5P amplified products were purified using the RapidTips (Diffinity Genomics); 12S and 16S amplified products were purified using ExoSap IT (Amershan Biosciences). They were subsequently sequenced bidirectionally by GATC Biotech AG (Konstanz, Germany).

Sequence trace files were individually edited and the primer sequences were removed. The obtained sequences were aligned using Clustal W in MEGA v. 7.0 (Kumar et al. 2016). COI-5P sequences were checked for possible stop codons, indels or unusual amino acid sequences (see Song et al. 2008). BOLD Identification System tool (BOLD-IDS) (Ratnasingham \& Hebert 2007) and GenBank BLASTn searchs (Altschul et al. 1990) were used to confirm if the sequences obtained for the new species match with existing taxa in the public databases. Available DNA barcodes belonging to the same genus were included in our alignment. The neighbour joining method was carried out to calculate intra- and interspecific distances using the Kimura-2-parameter (K2P) model (Kimura 1980). A data set was created in BOLD (Data set ID-HETSPP https://doi.org/10.5883/DS-HETSPP) comprising the COI sequences generated in this study plus the available sequences of Heteralepas specimens. All original sequences generated in this study were submitted to GenBank and correspond to accessions numbers MF695097 - MF695101, MF695104 - MF695108 and MF695113 - MF695121, including the sequences of the hydrozoan Oceania armata.

\section{Results}

\section{Taxonomic description}

Infraclass Cirripedia Burmeister, 1834

Superorder Thoracica Darwin, 1854

Order Lepadiformes Buckeridge \& Newman, 2006

Suborder Heteralepadomorpha Newman, 1987

Family Heteralepadidae Nilsson-Cantell, 1921 Heteralepas Pilsbry 1907

Heteralepas gettysburgensis sp. nov. urn:1sid:zoobank.org:act:6F9E2643-558E-4799-9FA8-EBAB9B3D04B9

Figs 2-6 


\section{Diagnosis}

Demarcation between capitulum and peduncle clear. Capitulum wider than capitulo-peduncular junction. Capitulum slightly longer than peduncle, both with folds. Carinal margin thickened. Aperture more than $1 / 3$ and less than $1 / 2$ height of the capitulum, with crenulated lips. Lips surrounding aperture clearly set off from the surrounding capitulum by a demarcation border. Mandible with four teeth covered by fine setae, as well as its posterior side. Lower margin of the teeth with numerous pectinations: the first tooth with ten, the second, third and fourth ones with five, five and six pectinations, respectively. First maxilla with two strong acuminate teeth of unequal length on the upper angle.

\section{Etymology}

The specific epithet alludes to the location where the specimens were collected: the Gettysburg Seamount, Gorringe Bank, in the Madeira-Tore geologic complex.

\section{Material examined}

\section{Holotype:}

NORTH-EAST ATLANTIC: located approximately $200 \mathrm{~km}$ off the southwestern coast of Portugal, Gettysburg Seamount, Gorringe Bank, Madeira-Tore geological complex, 36 $34^{\prime} 42.46^{\prime \prime}$ N,

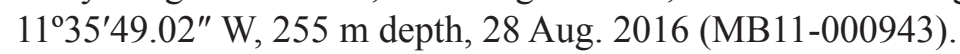

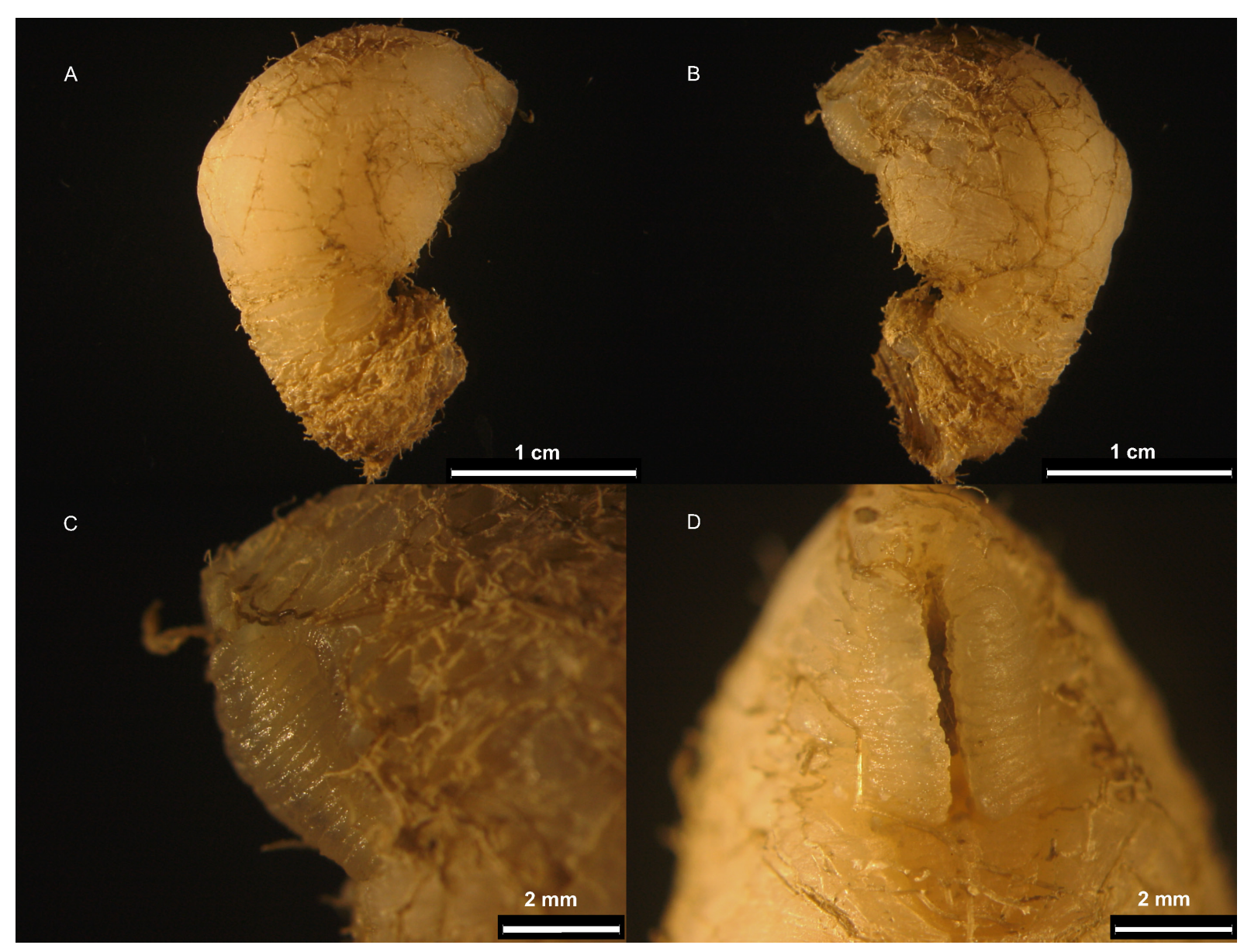

Fig. 2. External morphology of Heteralepas gettysburgensis sp. nov. (holotype) A-B. Side views showing the capitulum and peduncle. C. Side view of the aperture. D. Front view of the aperture. 


\section{Paratypes:}

NORTH-EAST ATLANTIC: 14 specimens, same data as for holotype (MB11-000944 - MB11-000957).

\section{Description}

The fresh specimens were translucent yellowish, allowing observation of the cirri movement inside the capitulum. Demarcation between capitulum and peduncle clear. Capitulum wider than capitulo-

A

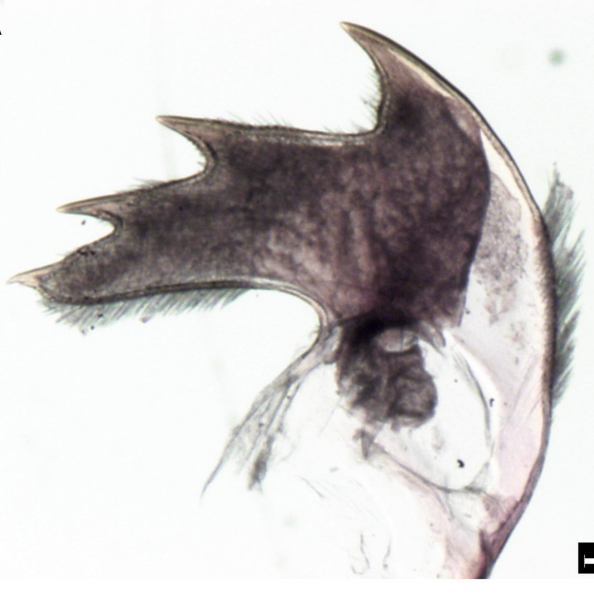

C

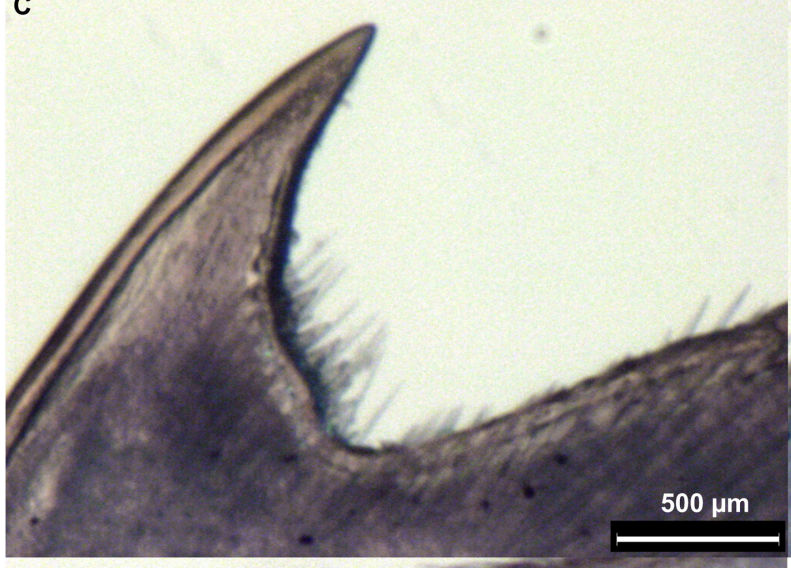

E

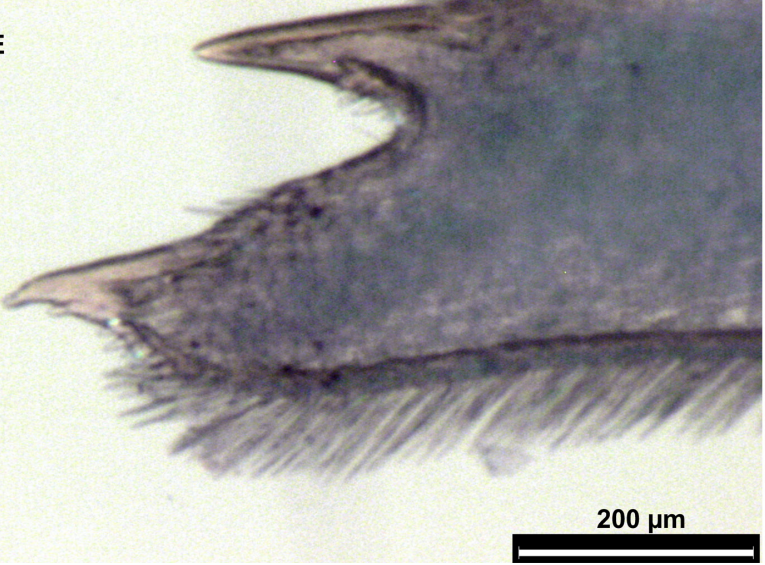

Fig. 3. Line drawings and pictures of the mouth parts of Heteralepas gettysburgensis sp. nov. (holotype) A-B. Mandible. C. Tooth I. D. Tooth II. E. Tooth III. F. Tooth IV.

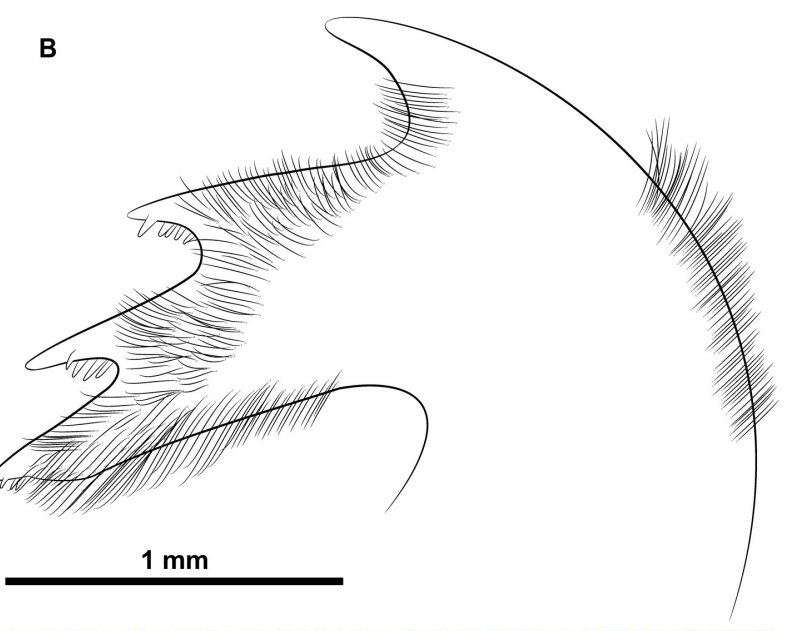

D
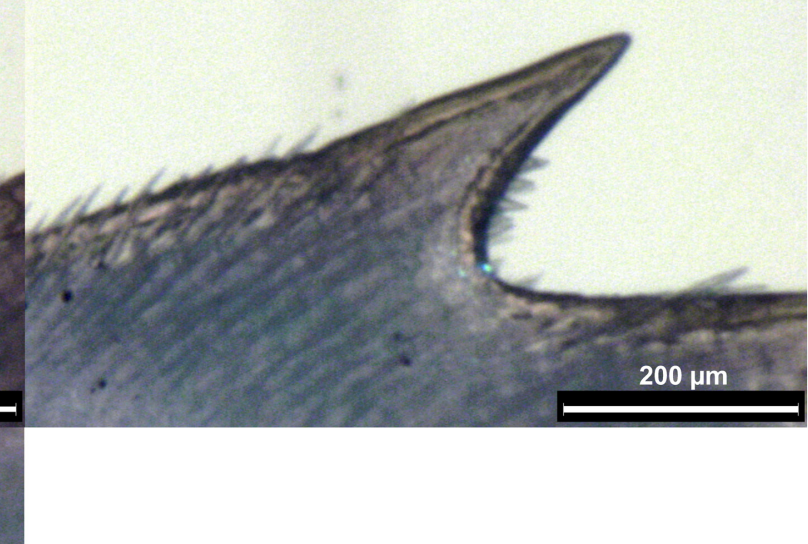

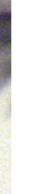

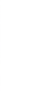


peduncular junction (Fig. 2A-B). Capitulum 1.2 to 1.6 times longer than peduncle, cylindrical. Both peduncle and capitulum with folds. Aperture more than $1 / 3$ and less than $1 / 2$ of the capitulum height. Lips surrounding the aperture crenulated and clearly set off from the surrounding capitulum by a demarcation border (Fig. 2C-D). Carinal margin thickened. Mandible (Fig. 3A-B) with four teeth covered by fine setae as well as its posterior side. Lower margin of the teeth with pectinations: first tooth

A

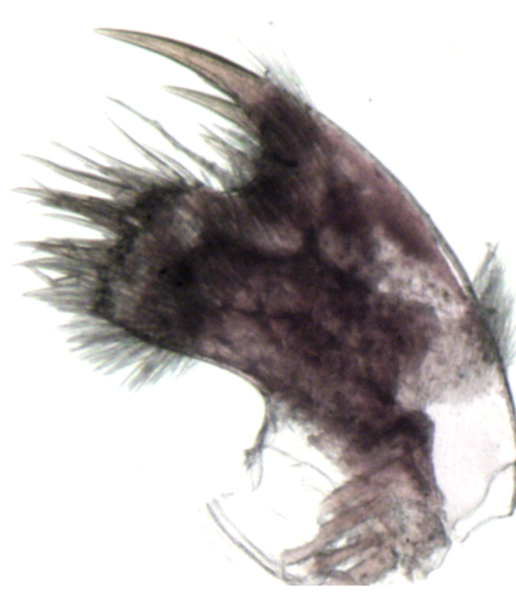

$1 \mathrm{~mm}$

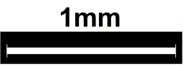

C

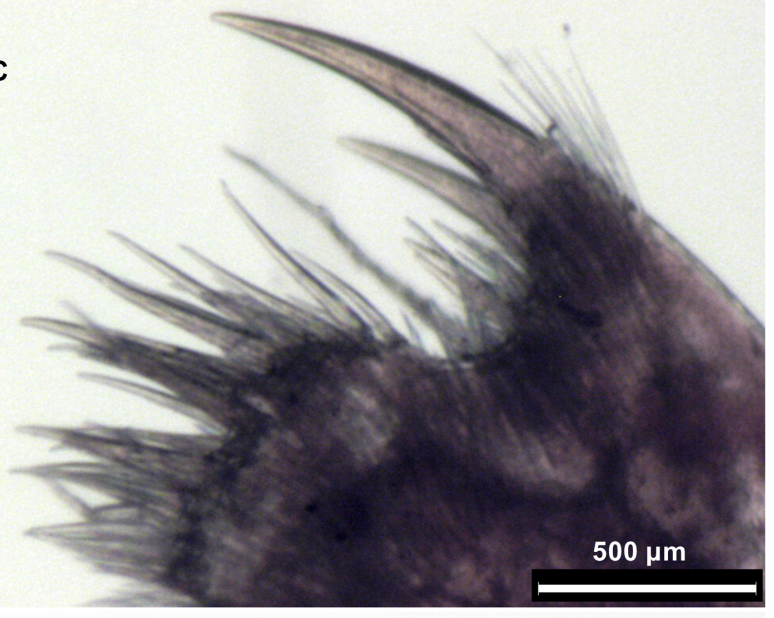

D

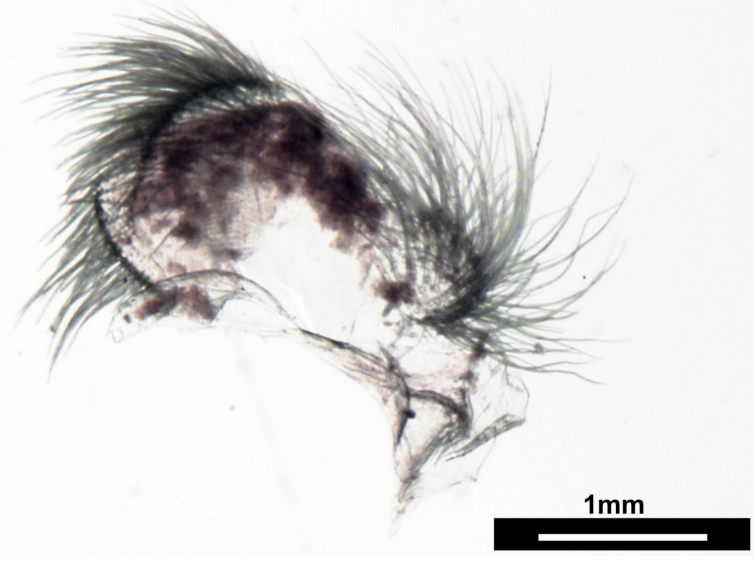

\section{B}
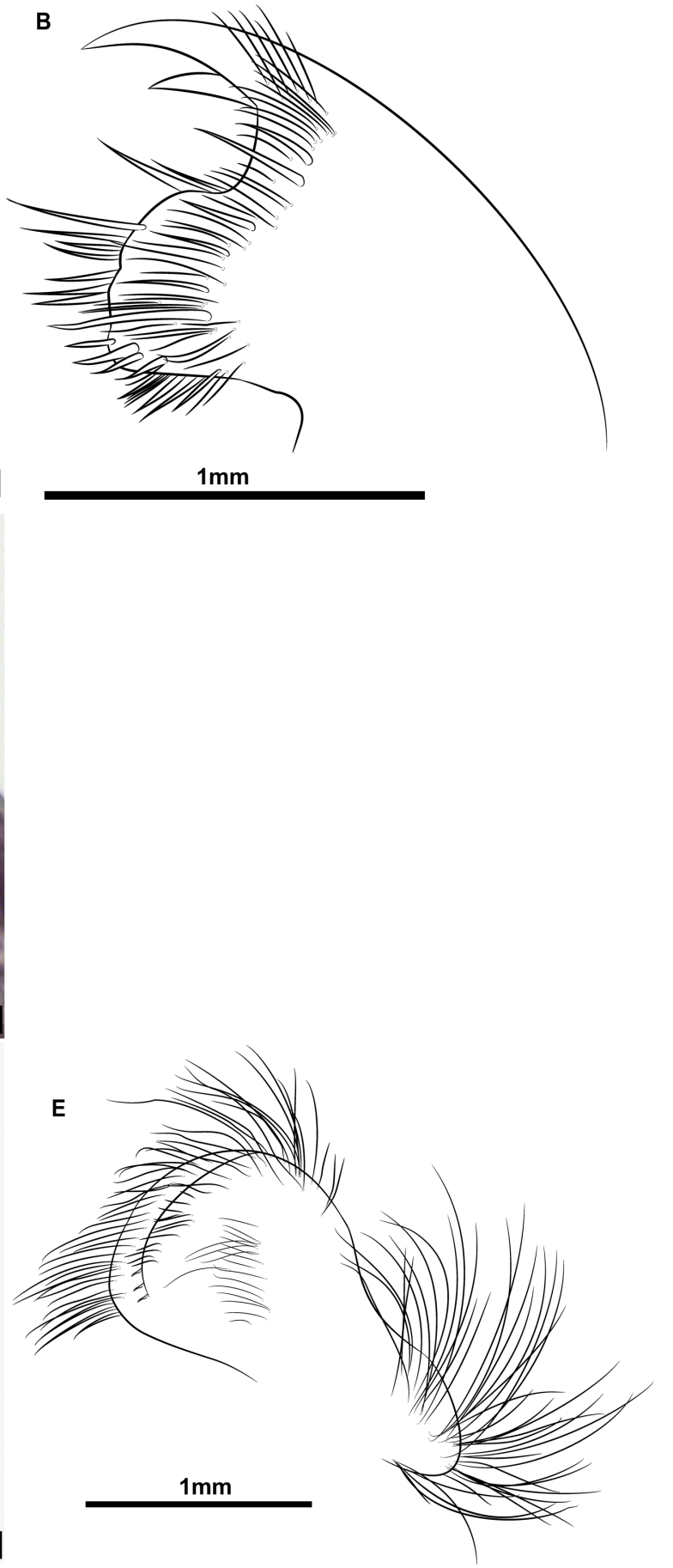

Fig. 4. Line drawings and pictures of the mouth parts of Heteralepas gettysburgensis sp. nov. (holotype) A-B. Maxilla I. C-D. Maxilla II. 
with ten, second, third and fourth ones with five, five and six pectinations, respectively (Fig. 3C-F). Distance between first and second tooth 1.5 times that between second and third tooth. Latter distance similar to the distance between third and fourth tooth. First maxilla deeply notched, with two strong acuminate teeth of unequal length on upper angle, numerous setae and short to long spines on the cutting margin. Posterior margin with a dense clump of fine setae. (Fig. 4A-C).Second maxilla with two lobes covered with numerous long serrulate setae, those on posterior lobe longer than those on anterior lobe (Fig. 4D-E). Cirral setation lasiopod. Cirrus I separated from posterior pairs, with unequal rami. Anterior ramus slightly shorter and wider at base than posterior ramus (Fig. 5A-B). Both with numerous setae on upper and lower margins. Base of cirrus I with one filamentous appendage. Cirrus II with anterior ramus slightly shorter than posterior ramus (Fig. 6A). Anterior and posterior rami of cirri III and IV very similar (Fig. 6B-C). Cirri V and VI similar (Fig. 6D and 4C-D, respectively), with inner rami atrophied. Inner ramus of cirrus VI shorter than inner ramus of cirrus V. Caudal appendage slightly longer than pedicel of cirrus VI (Fig. 5E-F). Penis relatively long, annulated, with numerous long and short fine setae distally scattered throughout (Fig. 5G-H). Table 1 displays the measurements, ratios, mean, standard deviation and coefficient of variation concerning the morphological characters mentioned.

\section{Discussion}

All specimens were collected from the same site, at a depth of $255 \mathrm{~m}$ in the northeastern Atlantic. Seven species occur in the Atlantic: H. belli (Gruvel, 1902), H. cantelli Buhl-Mortensen \& Newman, 2004, H. cornuta (Darwin, 1851), H. lankesteri (Gruvel, 1900), H. luridas Zevina, 1975, H. microstoma (Gruvel, 1901) and H. segonzaci Young, 2001, of which only three species occur in the east Atlantic (H. cornuta, H. microstoma and $H$. segonzaci). The new species differs distinctly from $H$. cornuta due to the absence of conspicuous triangular projections in the capitulum (Fig. 2A-B). The species $H$. microstoma has a peduncle much longer than the capitulum, being the opposite of our specimens, where the capitulum is slightly longer than the peduncle. The original description by Gruvel (1902) gives an account of the number of articles of cirrus I (inner and outer rami), the inner rami of cirri $\mathrm{V}$ and VI and the caudal appendage. All cirri have a greater number of articles than our specimens except the caudal appendage (Table 2). The peduncle of $\mathrm{H}$. segonzaci, from a depth of $2235 \mathrm{~m}$, is three times shorter than the capitulum and the aperture is more than half the length of the capitulum (Young, 2001) while our specimens have an aperture length less than half that of the capitulum, and the rami of cirri III and IV have fewer articles than $H$. segonzaci. Comparing with the other species recorded from the western Atlantic, $H$. belli has the capitulum shorter than the peduncle and the cuticle is almost smooth, with some irregular folds (Gruvel, 1902), while our specimens have the capitulum longer than the peduncle and the cuticle with numerous folds. Moreover, in $H$. bellii the aperture is half as high as the capitulum height (Gruvel, 1902) while in our species it is less than half its height. In H. lankesteri the capitulum is approximately as long as the peduncle (ratio length of capitulum to length of peduncle $(\mathrm{C} / \mathrm{P})$ varies from 0.6 to 1.3 ) (Gruvel, 1900), while in our specimens the ratio varies between 1.2 and 1.6. The cirri rami with a different number of articles and the non-pectinated mandible of H. lankesteri (Gruvel, 1900) also distinguish it from our species (Table 2). Finally, the small size of $H$. luridas (maximum registered size $9.5 \mathrm{~mm}$ ), from the Caribbean, and the smaller number of articles of all cirri rami (Zevina, 1975) strongly distinguish it from our specimens (Table 2).

Regarding the species outside of the Atlantic, H. japonica Aurivillius, 1892 and H. canci Chan, Tsang \& Shih, 2012 are the most similar species externally, probably due to the large morphological variability of $H$. japonica, unlike the species analyzed in this study (Table 1). However, they have crests on the carinal region of the capitulum, the rami of the cirri have fewer articles than our specimens and the ratio 'height of aperture/height of capitulum' is higher (Chan et al., 2009). The teeth of the mandible of $H$. japonica appear to be without pectinations or might have low pectinations on the lower margins of teeth 1-3, especially 2 and 3 (Buhl-Mortensen \& Newman 2004), while the new species exhibits 


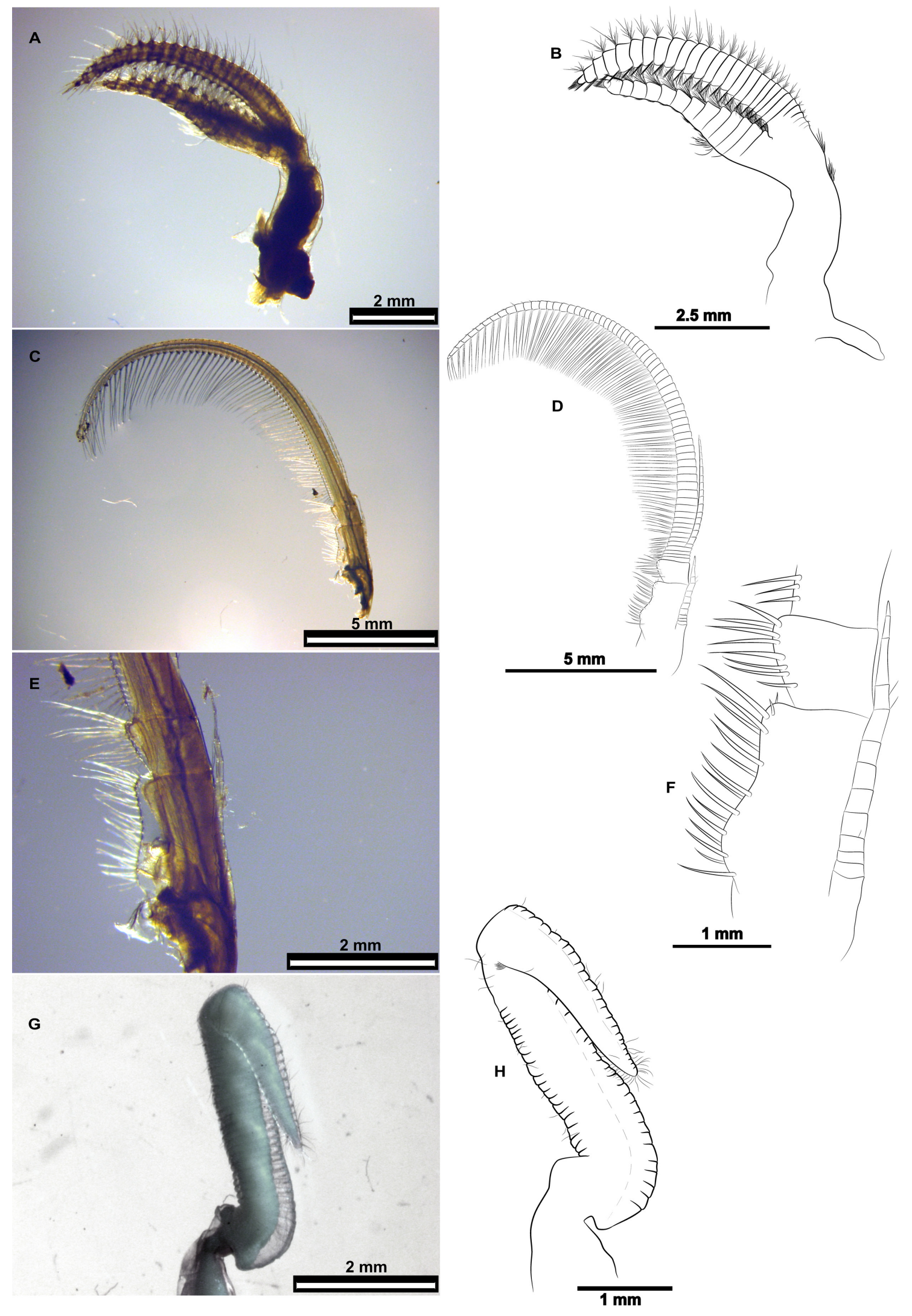

Fig. 5. Line drawings and pictures of Heteralepas gettysburgensis sp. nov. (holotype) A-B. Cirrus I. C-D. Cirrus VI. E-F. Caudal appendage. G-H. Penis. 
numerous pectinations on the lower margin of the four teeth. Also, the maximum length of the peduncle and capitulum of H. japonica reported by Buhl-Mortensen \& Newman (2004) is 11.6 and $3.6 \mathrm{~cm}$ respectively, quite distinct from the new species described in this study (1.4 and $1.6 \mathrm{~cm}$, respectively). On the other hand, the sequences of the COI obtained for our specimens had divergences of 16 to $21 \%$ with $H$. japonica and 16 to $17 \%$ with $H$. canci (Chan et al. 2009). The intraspecific distances obtained for our specimens were 0.3 to $0.7 \%$. Many studies have been carried out using the mitochondrial DNA sequences of the COI-5P, which have confirmed that DNA barcodes (Hebert et al. 2003) are a reliable tool to discriminate species of crustaceans (Lobo et al. 2013, 2016), including cirripedes (Chan et al. 2009). Ratnasingham \& Hebert (2013) suggested that $2.2 \%$ of average intraspecific distance is a reference threshold for within-species boundaries, which is quite far from the divergences found in this study. In addition, the marker $12 \mathrm{~S}$ presented divergences approximately of $6.5 \%$ and $7.5 \%$, with the species $H$. canci and $H$. japonica, respectively, being within the expected values for barnacle species within the same genus (Chan et al. 2007, 2009). The marker $16 \mathrm{~S}$ also showed $7 \%$ of genetic divergence with the only specimen of Heteralepas (unidentified) available in public databases (Schiffer \& Herbig 2016, GenBank accession KT947465), which is in accordance with the results obtained for other crustaceans (Brasher et al. 1992; Machado et al. 1993). H. adiposa Zevina, 1982 and H. cygnus Pilsbry, 1907, are similar to H. microstoma, but they differ from it in having numerous small calcareous knobs, four mandible teeth, and a great number of caudal segments (Zevina \& Kolbasov 2000). Therefore, their diagnostic characters are also distinct from the specimens analyzed in this study. H. mystacophora Newman, 1964 has a smooth capitulum and the superior margins of the second and third teeth of the

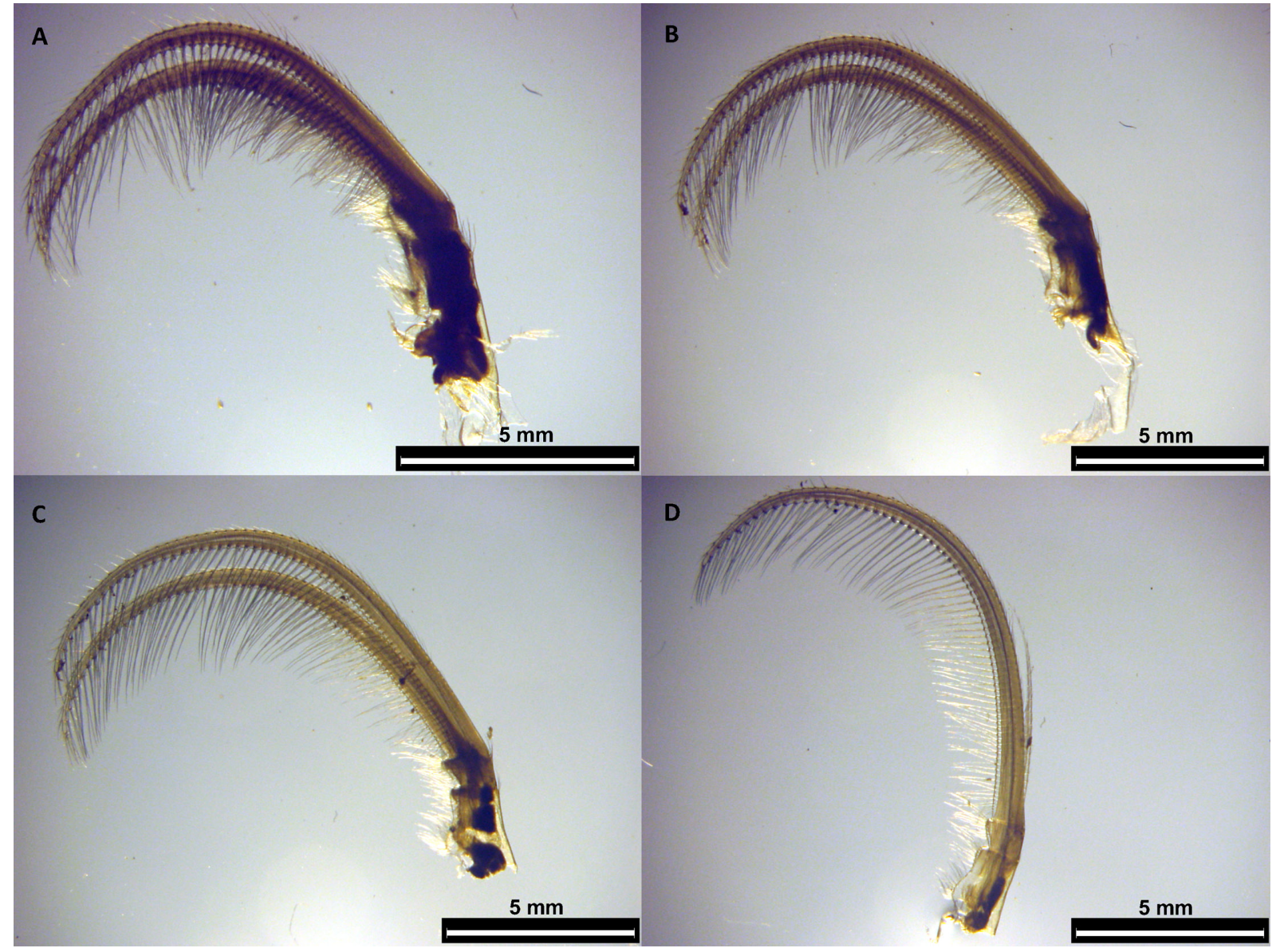

Fig. 6. Pictures of Heteralepas gettysburgensis sp. nov. (holotype) A. Cirrus II. B Cirrus III. C. Cirrus IV. D. Cirrus V. 
Table 1. External and internal morphological variation for specimens analyzed in this study. (- lack of information.)

\begin{tabular}{|c|c|c|c|c|c|c|c|c|c|c|c|c|c|c|}
\hline & & H1 & $\mathrm{H} 2$ & $\mathrm{H} 3$ & H4 & H5 & H6 & $\mathrm{H} 7$ & $\mathrm{H} 8$ & H9 & H10 & Mean & $\begin{array}{l}\text { Std } \\
\text { dev }\end{array}$ & $\begin{array}{l}\text { Coefficient } \\
\text { of variation }\end{array}$ \\
\hline \multirow[t]{2}{*}{ Capitulum } & Width & 0.87 & 1.1 & 0.88 & 0.95 & 1.08 & 0.92 & 1.12 & 0.96 & 0.96 & 1.18 & 1.0 & 0.1 & 0.09 \\
\hline & Length & 1.47 & 1.45 & 1.33 & 1.5 & 1.55 & 1.34 & 1.54 & 1.53 & 1.38 & 1.58 & 1.5 & 0.1 & 0.05 \\
\hline \multirow[t]{3}{*}{ Peduncle } & Width & 0.76 & 0.75 & 0.64 & 0.72 & 0.84 & 0.82 & 0.81 & 0.82 & 0.81 & 0.93 & 0.8 & 0.1 & 0.07 \\
\hline & Length & 1.1 & 0.91 & 0.97 & 1.03 & 1.28 & 1.13 & 1.08 & 1.19 & 0.95 & 1.36 & 1.1 & 0.1 & 0.10 \\
\hline & $\mathrm{C} / \mathrm{P}$ & 1.34 & 1.59 & 1.371 & 1.456 & 1.21 & 1.19 & 1.43 & 1.29 & 1.45 & 1.16 & 1.3 & 0.1 & 0.08 \\
\hline \multirow[t]{2}{*}{ Aperture } & Length & 0.61 & 0.47 & 0.5 & 0.57 & 0.57 & 0.49 & 0.58 & 0.54 & 0.56 & 0.69 & 0.6 & 0.0 & 0.08 \\
\hline & $\mathrm{A} / \mathrm{C}$ & 0.41 & 0.32 & 0.376 & 0.38 & 0.37 & 0.37 & 0.38 & 0.35 & 0.41 & 0.44 & 0.4 & 0.0 & 0.06 \\
\hline \multirow[t]{2}{*}{$\begin{array}{l}\text { Cirrus I } \\
\text { Articles }\end{array}$} & $\begin{array}{l}\text { Inner } \\
\text { ramus }\end{array}$ & 13 & 15 & 14 & 13 & 14 & 16 & 14 & 15 & 14 & 15 & 14.3 & 0.8 & 0.05 \\
\hline & $\begin{array}{l}\text { Outer } \\
\text { ramus }\end{array}$ & 28 & 28 & 28 & 28 & 28 & 28 & 29 & 24 & 30 & 28 & 27.9 & 0.8 & 0.03 \\
\hline \multirow[t]{2}{*}{$\begin{array}{l}\text { Cirrus II } \\
\text { Articles }\end{array}$} & $\begin{array}{l}\text { Inner } \\
\text { ramus }\end{array}$ & 51 & 50 & 46 & 52 & 51 & 53 & 51 & 48 & 53 & 51 & 50.6 & 1.6 & 0.03 \\
\hline & $\begin{array}{l}\text { Outer } \\
\text { ramus }\end{array}$ & 66 & 58 & 59 & 61 & 59 & 63 & 64 & 58 & 64 & 59 & 61.1 & 2.5 & 0.04 \\
\hline \multirow[t]{2}{*}{$\begin{array}{l}\text { Cirrus III } \\
\text { Articles }\end{array}$} & $\begin{array}{l}\text { Inner } \\
\text { ramus }\end{array}$ & 65 & 67 & 61 & 65 & 69 & 67 & 66 & 62 & 68 & 61 & 65.1 & 2.3 & 0.04 \\
\hline & $\begin{array}{l}\text { Outer } \\
\text { ramus }\end{array}$ & 66 & 67 & 62 & 71 & 72 & 70 & 65 & 66 & 71 & 62 & 67.2 & 3.0 & 0.05 \\
\hline \multirow[t]{2}{*}{$\begin{array}{l}\text { Cirrus IV } \\
\text { Articles }\end{array}$} & $\begin{array}{l}\text { Inner } \\
\text { ramus }\end{array}$ & 67 & 67 & 61 & 70 & 73 & 69 & 71 & 65 & 75 & 64 & 68.2 & 3.4 & 0.05 \\
\hline & $\begin{array}{l}\text { Outer } \\
\text { ramus }\end{array}$ & 71 & 68 & 69 & 73 & 75 & 71 & 71 & 66 & 75 & 74 & 71.3 & 2.4 & 0.03 \\
\hline \multirow[t]{2}{*}{$\begin{array}{l}\text { Cirrus V } \\
\text { Articles }\end{array}$} & $\begin{array}{l}\text { Inner } \\
\text { ramus }\end{array}$ & 69 & 70 & 64 & 72 & 73 & - & 73 & 71 & 78 & 67 & 70.8 & 2.9 & 0.04 \\
\hline & $\begin{array}{l}\text { Outer } \\
\text { ramus }\end{array}$ & 22 & 19 & 17 & 22 & 27 & 19 & 26 & 21 & 19 & 20 & 21.2 & 2.4 & 0.12 \\
\hline \multirow[t]{3}{*}{$\begin{array}{l}\text { Cirrus VI } \\
\text { Articles }\end{array}$} & $\begin{array}{l}\text { Inner } \\
\text { ramus }\end{array}$ & 70 & 69 & 60 & 71 & 76 & 70 & 73 & 64 & 78 & 67 & 69.8 & 3.8 & 0.06 \\
\hline & $\begin{array}{l}\text { Outer } \\
\text { ramus }\end{array}$ & 20 & 18 & 17 & 17 & 17 & 17 & 21 & 20 & 18 & 19 & 18.4 & 1.3 & 0.07 \\
\hline & $\begin{array}{l}\text { Caudal } \\
\text { appendage }\end{array}$ & 13 & 13 & 13 & 13 & 16 & 13 & 16 & 13 & 11 & 8 & 12.9 & 1.4 & 0.11 \\
\hline
\end{tabular}

mandible support several widely spaced spinules (Zullo \& Newman, 1964), while the species described here presents a wrinkled capitulum and has spinules in the inferior margin in the four teeth of the mandible. The capitulum of H. nicobarica Annandale, 1909 is indistinctly separated from the peduncle, the aperture height is $1 / 4$ of the capitulum height and the peduncle is similar to or longer than the capitulum (Annandale, 1909). Contrarily, the new species presents a clear demarcation between capitulum and peduncle, the aperture height is $>1 / 3$ and $<1 / 2$ of the capitulum height and the peduncle is shorter than the capitulum (see Table 1). In H. rex (Pilsbry, 1907), the capitulum is almost as long as the peduncle, and lips are slightly crenulated or irregularly warty and do not protrude in adults (Pilsbry, 1907). In our specimens the capitulum is slightly longer than the peduncle and the lips are clearly crenulated and protruding. In H. utinomii Newman, 1960, the length of the peduncle is one third of that of the capitulum (Newman, 1960), which distinguishes it from our specimens whose peduncle is only slightly shorter than the capitulum. 
Table 2. Comparison of diagnostic characters between the new species $H$. gettysburgensis sp. nov. and H. belli (Gruvel, 1902), H. canci Chan, Tsang \& Shih, 2012, H. cantelli Buhl-Mortensen \& Newman, 2004, H. japonica Aurivillius, 1892, H. lankesteri (Gruvel, 1900), H. microstoma (Gruvel, 1901) and H. segonzaci Young, 2001. The table was based on Buhl-Mortensen \& Newman (2004). C/P = Ratio of length of capitulum (C) to length of peduncle (P); A/C = Ratio of height of aperture (A) to height of capitulum $(\mathrm{C})$. Characters coincident with the new species are underlined.

\begin{tabular}{|c|c|c|c|c|c|c|c|c|c|c|}
\hline \multicolumn{2}{|l|}{ Heteralepas species } & belli & canci & cantelli & japonica & lankesteri & luridas & microstoma & segonzaci & $\begin{array}{l}\text { gettysburgensis } \\
\text { sp. nov. }\end{array}$ \\
\hline \multicolumn{2}{|c|}{$\begin{array}{l}\text { Demarcation between capitulum \& } \\
\text { peduncle }\end{array}$} & $\underline{\text { Clear }}$ & $\underline{\text { Varying }}$ & Weak & & $\underline{\text { Clear }}$ & & Weak & & Clear \\
\hline \multicolumn{2}{|c|}{$\begin{array}{l}\text { Width of capitulum to capitulo- } \\
\text { peduncular junction }\end{array}$} & $\underline{\text { Wider }}$ & $\underline{\text { Varying }}$ & $\begin{array}{l}\text { Slightly } \\
\text { wider } \\
\text { carinal } \\
\text { side }\end{array}$ & & $\underline{\text { Wider }}$ & & $\begin{array}{l}\text { Slightly } \\
\text { wider }\end{array}$ & & Wider \\
\hline \multirow[t]{2}{*}{ Capitulum } & Width & 2.5 & & 2 & $\underline{0.6-2.3(1.5)}$ & $\underline{1.2-2.0}$ & & 2.3 & & $0.9-1.2(1)$ \\
\hline & Length & 1.6 & & 3 & $\underline{0.9-3.6(2.0)}$ & $1.7-2.2$ & & 1.7 & & $1.3-1.6(1.5)$ \\
\hline \multirow[t]{3}{*}{ Peduncle } & Width & $\underline{0.95}$ & & 1.2 & $\underline{0.5-1.9(0.9)}$ & $\underline{0.9-1.3}$ & & $\underline{0.9}$ & & $0.6-0.9(0.8)$ \\
\hline & Length & 3.2 & & 3 & $\underline{0.5-11.6(3.8)}$ & $\underline{1.3-3.8}$ & & 2.4 & & $0.9-1.4(1.1)$ \\
\hline & $\mathrm{C} / \mathrm{P}$ & 0.5 & & 1.0 & $\underline{0.2-1.8(0.5)}$ & $\underline{0.6-1.3}$ & & 0.7 & 3 & $1.2-1.6(1.4)$ \\
\hline \multicolumn{2}{|l|}{$\begin{array}{l}\text { Carinal margin } \\
\text { thickened }\end{array}$} & $\underline{\text { Yes }}$ & & No & Varying & $\underline{\text { Yes }}$ & & $\underline{\text { Yes }}$ & $\underline{\text { Yes }}$ & Yes \\
\hline \multirow[t]{6}{*}{ Aperture } & Length & & & & & & & & & $0.5-0.7(0.6)$ \\
\hline & $\mathrm{A} / \mathrm{C}$ & $1 / 2$ & & $1 / 2$ & $1 / 2$ & $1 / 3$ & & $1 / 2 ?$ & $>1 / 2$ & $>1 / 3<1 / 2$ \\
\hline & $\begin{array}{l}\text { Flaring from } \\
\text { side }\end{array}$ & $\underline{\text { Yes }}$ & & Partly & No & $\underline{\text { Yes }}$ & & No? & & Yes \\
\hline & Crenulated & No & & Slightly & & $\underline{\text { Conspicuously }}$ & & & & Yes \\
\hline & $\begin{array}{c}\text { Lower margin } \\
\text { demarcated }\end{array}$ & No & & No & & $\underline{\text { Yes }}$ & & & & Yes \\
\hline & Tubular & ?Yes & & No & No & ?Yes & & $\underline{\text { Yes }}$ & & Yes \\
\hline \multirow[t]{2}{*}{ Cirrus I Articles } & Inner ramus & & 6 & 18 & $10-12$ & $\underline{13}$ & $\underline{13}$ & 17 & $\underline{14-15}$ & $13-16$ \\
\hline & Outer ramus & & 12 & $\underline{24}$ & $16-18$ & 21 & 22 & 32 & $\underline{27-28}$ & $24-30$ \\
\hline \multirow[t]{2}{*}{ Cirrus II Articles } & Inner ramus & & 24 & 42 & & $\underline{50}$ & 35 & & $\underline{50-54}$ & $46-53$ \\
\hline & Outer ramus & & 26 & 51 & & 55 & 40 & & $\underline{64-66}$ & $58-66$ \\
\hline \multirow[t]{2}{*}{ Cirrus III Articles } & Inner ramus & & 47 & 56 & & 50 & 40 & & $72-75$ & $61-69$ \\
\hline & Outer ramus & & 46 & 57 & & 55 & 41 & & $73-79$ & $62-72$ \\
\hline \multirow[t]{2}{*}{ Cirrus IV Articles } & Inner ramus & & 47 & 56 & & 50 & 41 & & $76-79$ & $61-71$ \\
\hline & Outer ramus & & 47 & 58 & & 55 & 41 & & $\underline{75-79}$ & $66-75$ \\
\hline \multirow[t]{2}{*}{ Cirrus V Articles } & Inner ramus & $\underline{27}$ & $\underline{19}$ & $\underline{25}$ & $\underline{13-29}$ & $\underline{19}$ & 15 & 29 & $\underline{3+-29}$ & $19-27$ \\
\hline & Outer ramus & & 50 & 60 & $\underline{36-69}$ & $\underline{74-92}$ & 57 & & $\underline{77-78}$ & $64-78$ \\
\hline \multirow[t]{3}{*}{ Cirrus VI Articles } & Inner ramus & 27 & $\underline{18}$ & 22 & $\underline{13-27}$ & 16 & 14 & 26 & $22-23$ & $17-21$ \\
\hline & Outer ramus & & 49 & 60 & $\underline{37-68}$ & $\underline{89}$ & 54 & & $\underline{75-81}$ & $64-78$ \\
\hline & $\begin{array}{c}\text { Caudal } \\
\text { appendage }\end{array}$ & $\underline{15}$ & 6 & $\underline{13}$ & $\underline{4-12}$ & $\underline{10}$ & & $\underline{15}$ & $\underline{13-15}$ & $8-16$ \\
\hline Mouth parts & $\begin{array}{l}\text { Mandible } \\
\text { pectination }\end{array}$ & $\underline{\text { Yes }}$ & & $\underline{\text { Yes }}$ & $\underline{\text { Yes }}$ & No & & $\underline{\text { Yes }}$ & & Yes \\
\hline
\end{tabular}




\section{Final Remarks}

Specimens of Heteralepas are not encountered often since they live in deep-sea environments. The combination of the morphological and molecular data, reveals that the new species Heteralepas gettysburgensis sp. nov. is distinct from all the species described so far for this genus. It is recorded from the type locality at a depth of $255 \mathrm{~m}$ in the Gettysburg Seamount of the Gorringe Bank only, located in the Portuguese Exclusive Economic Zone, approximately $200 \mathrm{~km}$ off the southwestern coast of mainland Portugal. Due to its outstanding biodiversity, including several priority species and habitats, the Portuguese Institute for Nature Conservation and Forests, proposed in 2015 to declare the Gorringe Bank as a Site of Community Importance (SCI) under the Natura 2000 network. The present work not only contributes to improve the knowledge of the benthic biodiversity in this deep-sea environment, but also provides both a morphological description and genetic data (three mitochondrial markers: COI-5P, $12 \mathrm{~S}$ and $16 \mathrm{~S}$ ), which will be a relevant contribution to help clarifying potential issues regarding the taxonomy of the genus Heteralepas.

\section{Acknowledgments}

The study was funded by EEA grants as part of the project BIOMETORE - Biodiversity in seamounts: the Madeira-Tore and Great Meteor (PT02_Call2_0001). We would like to express our gratitude to Cátia Bartilotti for the very useful comments and support, Maria José Gaudêncio for providing support with the photographs and to Victor Henriques for providing the map figure.

\section{References}

Altschul S.F., Gish W., Miller W., Myers E.W. \& Lipman D.J. 1990. Basic local alignment search tool. Journal of Molecular Biology 215: 403-410. https://doi.org/10.1016/S0022-2836(05)80360-2

Annandale N. 1909. An account of the Indian Cirripedia Pedunculata Part 1. Family Lepadidae (sensu stricto). Memoirs of the Indian Museum 2: 61-137.

Brasher D.J., Ovenden J.R. \& White R.W.G. 1992. Mitochondrial DNA variation and phylogenetic relationships of Jasus spp. (Decapoda: Palinuridae). Journal of Zoology 227 (1): 1-16. https://doi.org/10.1111/j.1469-7998.1992.tb04340.x

Buhl-Mortensen L. \& Newman W.A. 2004. A new pedunculate barnacle (Cirripedia: Heteralepadidae) from the Northwest Atlantic. Proceedings of the Biological Society of Washington 117 (3): 385-397.

Chan B.K., Tsang L.M. \& Chu K.H. 2007. Morphological and genetic differentiation of the acorn barnacle Tetraclita squamosa (Crustacea, Cirripedia) in East Asia and description of a new species of Tetraclita. Zoologica Scripta 36 (1): 79-91. https://doi.org/10.1111/j.1463-6409.2007.00260.x

Chan B.K.K., Tsang L.M. \& Shih F.L. 2009. Morphological and genetic differentiations of the stalked barnacle Heteralepas japonica Aurivillius, 1892, with description of a new species of Heteralepas Pilsbry 1907 from the Philippines. Raffles Bulletin of Zoology Supplement 20: 83-95.

Chan B.K.K. \& Southward A. 2010. Heteralepas Pilsbry, 1907. World Register of Marine Species. Available from http://marinespecies.org/aphia.php?p=taxdetails\&id=106095 [accessed 30 Apr. 2017].

Gruvel A. 1900. On new species of the genus Alepas (A. Lankesteri) from the collection of the British Museum. Annals and Magazine of Natural History 2: 7.

Gruvel A. 1902. VIII. Sur quelques Lépadides nouveuax de la Collection du British Museum. Transactions of the Linnean Society of London 8 (8): 277-295. 
Hebert P.D.N., Cywinska A., Ball S.L. \& deWaard J.R. 2003. Biological identifications through DNA barcodes. Proceedings of the Royal Society of London Series B: Biological Sciences 270: 313-321. https://doi.org/10.1098/rspb.2002.2218

Kimura M. 1980. A simple model for estimating evolutionary rates of base substitutions through comparative studies of nucleotide sequences. Journal of Molecular Evolution 16: 111-120. https://doi.org/10.1007/BF01731581

Kumar S., Stecher G. \& Tamura K. 2016. MEGA7: Molecular Evolutionary Genetics Analysis version 7.0 for bigger datasets. Molecular Biology and Evolution, 33 (7): 1870n-dash1874. https://doi.org/10.1093/molbev/msw054

Lobo J., Costa P.M., Teixeira M.A., Ferreira M.S., Costa M.H. \& Costa F.O. 2013. Enhanced primers for amplification of DNA barcodes from a broad range of marine metazoans. BMC ecology 13(1): 34. https://doi.org/10.1186/1472-6785-13-34

Lobo J., Ferreira M.S., Antunes I.C., Teixeira M.A.L., Borges L.M., Sousa R., Gomes P.A., Costa M.H., Cunha M.R. \& Costa F.O. 2016. Contrasting morphological and DNA barcode-suggested species boundaries among shallow-water amphipod fauna from the southern European Atlantic coast. Genome 60 (2): 147-157. https://doi.org/10.1139/gen-2016-0009

Machado E.G., Dennebouy N., Suarez M.O., Mounolou J.C. \& Monnerot M. 1993. Mitochondrial 16S-rRNA gene of two species of shrimps: sequence variability and secondary structure. Crustaceana 65 (3): 279-286. https://doi.org/10.1163/156854093X00711

Machida R.J., Miya M.U., Nishida M. \& Nishida S. 2002. Complete mitochondrial DNA sequence of Tigriopus japonicus (Crustacea: Copepoda). Marine Biotechnology 4 (4): 406-417. https://doi.org/10.1007/s10126-002-0033-x

Machida R.J., Miya M.U, Nishida M. \& Nishida S. 2004. Large-scale gene rearrangements in the mitochondrial genomes of two calanoid copepods Eucalanus bungii and Neocalanus cristatus (Crustacea), with notes on new versatile primers for the srRNA and COI genes. Gene 332: 71-78. https://doi.org/10.1016/j.gene.2004.01.019

Newman W.A. 1960. Five pedunculate cirripeds from the western Pacific, including two new forms. Crustaceana 1(2): 100-116.

Pilsbry H.A. 1907. The barnacles (Cirripedia) contained in the collections of the US National Museum. Vol. 60. US Government Printing Office.

Ratnasingham S. \& Hebert P.D.N. 2007. BOLD: The Barcode of Life Data System. Molecular Ecology Resources 7: 355-364. https://doi.org/10.1111/j.1471-8286.2007.01678.x

Ratnasingham S. \& Hebert P.D.N. 2013. A DNA-based registry for all animal species: The barcode index number (BIN) system. PLoS One 8: e66213. https://doi.org/10.1371/journal.pone.0066213

Schiffer P.H. \& Herbig H.G. 2016. Endorsing Darwin: global biogeography of the epipelagic goose barnacles Lepas spp. (Cirripedia, Lepadomorpha) proves cryptic speciation. Zoological Journal of the Linnean Society 177(3): 507-525. https://doi.org/10.1111/zoj.12373

Schubart C.D., Neigel J.E. \& Felder D.L. 2000. Use of the mitochondrial 16S rRNA gene for phylogenetic and population studies of Crustacea. Crustacean issues 12: 817-830.

Schubart C.D., Cuesta J.A. \& Felder D.L. 2002. Glyptograpsidae, a new brachyuran family from Central America: larval and adult morphology, and a molecular phylogeny of the Grapsoidea. Journal of Crustacean Biology 22 (1): 28-44.

https://doi.org/10.1651/0278-0372(2002)022[0028:GANBFF]2.0.CO;2 
Song H., Buhay J.E., Whiting M.F. \& Crandall K.A. 2008. Many species in one: DNA barcoding overestimates the number of species when nuclear mitochondrial pseudogenes are coamplified. Proceedings of the National Academy of Sciences of the United States of America 105: 13486-13491. https://doi.org/10.1073/pnas.0803076105

Young P.S. 2001. Deep-sea Cirripedia Thoracica (Crustacea) from the northeastern Atlantic collected by French expeditions. Zoosystema 23(4): 705-756.

Zevina G.B. 1975. Cirripedia Thoracica of the American Mediterranean. Transactions of the P.P. Shirshov Institute of Oceanology. V. 100. Scientific Studies of Caribbean Sea, Gulf of Mexico and adjacent waters. Academy of Sciences of the USSR: 233-258. (in Russian).

Zevina G.B. \& Kolbasov G.A. 2000. Barnacles of the genus Heteralepas (Thecostraca, Cirripedia, Thoracica) from the Canary Islands and the Azores. Description of mantle ultrastructure. Zoologichesky Zhurnal 79(11): 1275-1283. [in Russian].

Zullo V.A. \& Newman W.A. 1964. Thoracic Cirripedia from a South East Pacific Guyot. Pacific Science 18: $355-372$.

Manuscript received: 24 May 2017

Manuscript accepted: 11 September 2017

Published on: 20 December 2017

Topic editor: Rudy Jocqué

Desk editor: Jeroen Venderickx

Printed versions of all papers are also deposited in the libraries of the institutes that are members of the EJT consortium: Muséum national d'Histoire naturelle, Paris, France; Botanic Garden Meise, Belgium; Royal Museum for Central Africa, Tervuren, Belgium; Natural History Museum, London, United Kingdom; Royal Belgian Institute of Natural Sciences, Brussels, Belgium; Natural History Museum of Denmark, Copenhagen, Denmark; Naturalis Biodiversity Center, Leiden, the Netherlands; Museo Nacional de Ciencias Naturales-CSIC, Madrid, Spain; Real Jardín Botánico de Madrid CSIC, Spain. 